\title{
Higher triglyceride serum level increases atherosclerotic index in subjects 50-70 years of age
}

\author{
Martiem Mawi*, Fransisca Chondro*, and Juni Chudri*
}

\section{ABSTRACT}

\section{BACKGROUND}

Atherosclerosis, the underlying cause of heart attack, stroke and peripheral disease, is a main cause of morbidity and mortality worldwide. Hypercholesterolemia and hypertriglyceridemia are independent factors in the development and progression of atherosclerosis. The atherosclerotic index (AI) is a strong indicator of cardiovascular heart disease. The objective of this study was to determine the relationship between lipid serum level and AI in subjects 50-70 years of age.

\section{METHODS}

A study of cross-sectional design was conducted among male and female subjects 50-70 years of age. The inclusion criteria were: healthy, and capable of active communication. The exclusion criteria were: subjects not completing the study, currently consuming antihyperlipidemic drugs. Lipid profile comprising total cholesterol, low density lipoprotein (LDL), high density lipoprotein (HDL), triglycerides, and malondialdehyde (MDA), was analyzed using commercial kits. Systolic and diastolic blood pressure and body mass index was measured in all subjects. Atherogenic index was calculated from (total cholesterol - HDL cholesterol) / HDL cholesterol. Multiple linear regression was used to analyze the data.

\section{RESULTS}

Mean age of the subjects was $60.6 \pm 3.30$ years and there was a significant relationship of LDL cholesterol and triglycerides with AI ( $\beta=0.009$; $\mathrm{p}=0.000$ and $\beta=0.008 ; \mathrm{p}=0.000$, respectively). Triglyceride level was the most influencing factor for AI $(\beta=0.008$; Beta $=0.616$; $\mathrm{p}=0.000)$

\section{CONCLUSIONS}

Higher triglyceride levels increase AI in subjects 50-70 years of age. Subjects with high serum triglyceride level but without symptoms of cardiovascular disease should be examined for the development of coronary artery blockage.

Keywords : Atherosclerotic index, lipid profile, malondialdehyde, 5070 years of age
*Department of Physiology, Faculty of Medicine, Trisakti University

\section{Correspondence:} dr. Martiem Mawi, MS Department of Physiology, Faculty of Medicine, Trisakti University Jalan Kyai Tapa (Kampus B), Grogol, West Jakarta 11440 Mobile: +62816 1363811

Email: martiemmawi@yahoo.com

Univ Med 2015;34:205-12

DOI: 10.18051/UnivMed.2016.v35.205-212 pISSN: 1907-3062 / eISSN: 2407-2230

This open access article is distributed under a Creative Commons Attribution-Non Commercial-Share Alike 4.0 International License 


\section{Kadar trigliseride serum yang tinggi meningkatkan indeks aterosklerotik pada usia 50-75 tahun}

\section{ABSTRAK}

\section{LATAR BELAKANG}

Aterosklerosis merupakan penyebab dari stroke, serangan jantung dan penyakit vaskular yang dapat menimbulkan kematian. Hiperkolesterolemia dan hipertrigliseridemia merupakan faktor risiko penting terjadinya aterosklerosis. Indeks aterosklerotik (IA) merupakan indikator kuat untuk penyakit kardiovaskular. Penelitian ini bertujuan untuk menentukan hubungan antara kadar lipid serum dan indeks aterogenik pada usia 50-70 tahun.

\section{METODE}

Sebuah penelitian dengan rancangan potong silang dilakukan pada 80 subjek laki-laki dan perempuan berusia 50-70 tahun. Kriteria inklusi adalah subjek berbadan sehat dan mampu berkomunikasi secara aktif. Kriteria ekslusi: tidak mengikuti penelitian secara lengkap, memakan obat anti lipid. Pengukuran profil lipid meliputi kadar kolesterol total, low density lipoprotein (LDL), high density lipoprotein (HDL), dan malondialdehid (MDA), menggunakan kit komersial. Tekanan darah sistolik dan diastolik dan indeks massa tubuh (IMT) diukur pada semua subjek. Indeks aterogenik diukur berdasarkan (kadar kolesterol total - kolesterol HDL) / kolesterol HDL. Analisis regresi linear ganda digunakan untuk analisis data.

\section{HASIL}

Usia rata-rata subjek penelitian adalah 60,6 \pm 3,30 tahun dan terdapat hubungn yang bermakna antara kolesterolLDL dan trigliserid dengan IA, masing-masing dengan ( $\beta=0.009 ; p=0,000$ dan $\beta=0.008 ; p=0,000$. Kadar trigliserid merupakan faktor yang paling besar terhadap IA $(\beta=0.008 ;$ Beta $=0.616 ; p=0.000)$.

\section{KESIMPULAN}

Semakin tinggi kadar trigliseride serum semakin tinggi skor IA pada subjek berusia 50-70 tahun. Pada subjek dengan kadar trigliserid serum tinggi, walaupun tidak ditemukan gejala penyakit kardiovaskular harus dilakukan pemeriksaan lebih lanjut untuk memastikan ada tidaknya penyumbatan pembuluh darah terutama di arteria coronaria.

Kata kunci: Indeks aterogenik, profil lipid, malondialdehid, usia 50-70 tahun

\section{INTRODUCTION}

Cardiovascular disease is a worldwide major cause of morbidity and mortality. ${ }^{(1-3)}$ Atherosclerosis is considered to be a basic cause of heart attacks, stroke and peripheral vascular disease. Hypercholesterolemia and hypertriglyceridemia are important risk factors for the genesis of atherosclerosis and the progressivity of atherosclerotic lesions. ${ }^{(1)}$ The initial event in the induction of atherosclerosis is the accumulation of cells containing excessive amounts of lipids in the arterial wall. It has been demonstrated that increased production of reactive oxygen species (ROS) substantially influences the chronic inflammatory response in atherosclerosis. ${ }^{(4)}$ ROS reacts with a number of biomolecukes, such as lipids, carbohydrates, proteins, and nucleic acids, resulting in cellular dysfunction. Normally there is a balance between the prduction of free oxygen radicals and the antioxidant defense system. Antioxidant-oxidant imbalance induces oxidative stress as a result of excessive ROS formation. Oxidative stress is 
known to be a component of the mechanism of cellular and molecular tissue damage in a broad spectrum of human disease. ${ }^{(5)}$ Increased ROS causes vasoconstriction since it reduces the production of nitric oxide (NO), and increases platelet aggregation and neutrophil adhesion to vascular endothelium. ${ }^{(6-8)}$

The risk factors of atherosclerosis, such as hypercholesterolemia, diabetes mellitus, smoking, hypertension, and age, may increase the production of free ROS, not only by endothelial cells but also by smooth muscle and adventitial cells. Free radicals are extremely reactive chemical compounds, and the majority of molecules in the body may become a target of these free radicals, but lipids are their most frequent target. The cell membrane is a source of polyunsaturated fatty acids and is extremely vulnerable to attack by free radicals, a process known as lipid peroxidation. Lipid peroxidation leads to the formation of reactive products, some of which interact with proteins and DNA, thus giving rise to toxic and mutagenic components. ${ }^{(9)}$

One of the standards used to evaluate the condition of the vascular wall resulting from the atherosclerotic process is the atherogenic index (AI), which is calculated from the difference between total cholesterol concentration and HDL cholesterol concentration, divided by HDL cholesterol concentration. The atherogenic index is a strong indicator of cardiovascular disease..$^{(1,3)}$ The study of Nwagha et al ${ }^{(10)}$ shows a positive correlation of LDL cholesterol and triglycerides with AI in postmenopausal women. A study on women with preeclampsia showed an association between serum MDA level and AI. ${ }^{(11)}$ The study of Prakash and Rao found that hypertriglyceridemia is a risk factor for the atherogenic process, and high LDL cholesterol and triglyceride levels increase the risk of cardiovascular disease. ${ }^{(2)}$ Lafta ${ }^{(3)}$ found a positive association between increased triglycerides and incidence of cardiovascular disease.

Malondialdehydes (MDA) are lipid peroxidation products and indicators of oxidationinduced damage. MDA have been used for many years as biomarker of lipid peroxidation. The progress of the atherosclerotic process is associated with oxidative stress and can be followed up with measurement of MDA..$^{(1,11)}$ The study of Yang et al. ${ }^{(1)}$ compared hyperlipidemic and normolipidemic groups and showed a significantly positive association between MDA and AI. The investigators found a higher atherogenic index in the groups with increased lipid peroxidation levels. No informatiion could be found in the literature of studies showing an association of lipid and MDA levels with AI in healthy adults. The objective of the present study was to determine any association between lipid levels (total cholesterol, HDL cholesterol, LDL cholesterol), and MDA on the one hand and atherogenic index on the other in healthy subjects 50-70 years of age.

\section{METHODS}

\section{Study design}

This study used an experimental crosssectional design and was conducted at the Mampang Prapatan Subdictrict Health Center, South Jakarta from February until May 2014.

\section{Study subjects}

Males and females aged between 50 and 70 years and residing at 2 kelurahan (villages) in Mampang Prapatan Subdistrict, South Jakarta, were recruited into this study. The inclusion criteria were: capable of active communication, literate, physically healthy and not requiring help from others, and agreeing to sign informed consent. The exclusion criteria were: not participating in this study up to its completion, and current consumers of anti-lipid drugs.

The sample size was determined with the formula:

$$
\mathrm{N}=\left\{\frac{(\mathrm{Z} \alpha-\mathrm{Z} \beta)}{0.5 \times 1 \mathrm{n}(1-\mathrm{r}) /(1-\mathrm{r})}\right\}^{2}+3
$$

where Zá $=1.96$, Zâ $=0.84$, and $\mathrm{r}=0.61 .^{(1)}$ 
The minimum sample size required was 18 , but in this study it was increased to 80 , which is the sampe size for using one commercial kit.

\section{Anthropometric measurements}

Anthropometric assessment comprised determination of weight, height, and body mass index (BMI). Height was measured using a portable microtoise with an accuracy of $0.1 \mathrm{~cm}$. Weight was measured using Sage portable scales with an accuracy of $0.1 \mathrm{~kg}$. Body mass index was calculated from the formula weight $(\mathrm{kg}) /$ height $\left(\mathrm{m}^{2}\right)$ and categorized as follows: normal $\left(<23.0 \mathrm{~kg} / \mathrm{m}^{2}\right)$, overweight or obesity $(\geq 23.0 \mathrm{~kg} /$ $\mathrm{m}^{2}$ ), and obesity according to the criteria determined for Asians. ${ }^{(12)}$

\section{Laboratory investigations}

From each subject, a 10-ml blood sample was drawn from the cubital vein using plain tubes after an overnight fast of 12-14 hours and centrifuged at $3000 \mathrm{rpm}$ for 15 minutes. The serum was separated and placed into an automatic analyzer.

All determinations of lipid profile components (total cholesterol, LDL cholesterol, HDL cholesterol, and triglyceride concentrations) were performed spectrophotometrically using an Advia 1800 system and the respective Bayer reagent kits. All procedures produce a complex of a given color, the intensity of which can be spectrophotometrically determined and is proportional to the blood concentration of the lipid component to be assessed.

The principles of the lipid profile determinations are as follows. For total cholesterol determination, cholesterol esters in the sample are hydrolyzed by cholesterol esterase into free cholesterol. This is then oxidized by cholesterol oxidase into cholest-4-en-3-on and peroxides. The peroxides are reacted with 4-aminophenazone and phenol to form the colored 4-(p-benzoquinonemonoimino)-phenazone.

For LDL cholesterol determination, reagent No. 1 solubilizes chylomicrons, HDL and VLDL cholesterol to yield free cholesterol, which is subsequently oxidized into peroxides. The peroxides are then reacted with 4-aminoantipyrine. Next, reagent No. 2 releases the LDL from the LDL cholesterol produced in the first reaction so that the LDL is oxidized to form peroxides. These latter are reacted with N,N-bis(4-sulphobutyl)-mtoluidine-disodium (DSBmT) into a blue-violet colored complex.

For HDL cholesterol determination, HDL cholesterol is separated from other lipid components and solubilized by a specific detergent. The HDL cholesterol is then oxidized and released from its esters, thus forming peroxides. These are reacted with 4aminoantipyrine and DSBmT using peroxidase catalyst to form a red-colored complex.

For triglyceride concentration determination, the triglycerides in the sample are hydrolyzed into glycerol and free fatty acids. The glycerol is then phosphorylated to yield glycerol-3-phosphate, which is then oxidized into dihydroxy-acetonephosphate, forming peroxides. The peroxides are reacted with 4-aminophenazone to form the colored 4-(p-benzoquinone-monoimino)phenazone.

The atherogenic index was calculated from the formula: (total cholesterol - HDL cholesterol) /HDL cholesterol. ${ }^{(1)}$ Plasma MDA concentration was measured using thiobarbituric acid reactive substances (TBARS) according to the Satoh method. The pink-colored chromogens that are formed by the reaction of barbituric acid with MDA are measured at $530 \mathrm{~nm} .{ }^{(13)}$ The determination was performed at Prodia Laboratories using high-performance liquid chromatography (HPLC).

\section{Ethical clearance}

Ethical clearance was issued by the Research Ethics Commission, Faculty of Medicine, Trisakti University.

\section{Data analysis}

The Kolmogorov-Smirnov test was used to test for normality of the data distribution. Since the data were normally distributed, multiple 
regression analysis was used to determine the variables which the greatest influence on AI. A pvalue of $<0.05$ was declared to be statistically significant.

\section{RESULT}

The 80 study subjects who met the inclusion and exclusion criteria were between 50 to 70 years of age, comprising 20 males (25\%) and 60 females $(75 \%)$, with mean age of $60.06 \pm 3.30$ years. With regard to educational level, 6 subjects $(7.5 \%)$ had no education, 8 subjects (10\%) did not finish primary school, 25 subjects $(31.3 \%)$ finished primary school, 15 subjects (18.8\%) were junior high school graduates, 25 subjects (31.3\%) were senior high school graduates, and 1 subject (1.3\%) was of academic level. With regard to employment, 38 subjects (47.5\%) were employed and 42 subjects ( $52.5 \%$ ) were unemployed. Mean systolic blood pressure was $137.44 \pm 20.93$ $\mathrm{mmHg}$ and mean diastolic blood pressure 84.33 $\pm 11.08 \mathrm{mmHg}$. Mean body mass index was 25.94 $\pm 3.48 \mathrm{~kg} / \mathrm{m} 2$ (Tables 1 and 2).

Mean total cholesterol was $205.53 \pm 36.49$ $\mathrm{mg} / \mathrm{dL}$, mean LDL cholesterol $140.08 \pm 34.31$ $\mathrm{mg} / \mathrm{dL}$, mean HDL cholesterol was $48.33 \pm 8.56$ $\mathrm{mg} / \mathrm{dL}$, mean triglyceride concentration was $141.90 \pm 72.36 \mathrm{mg} / \mathrm{dL}$, mean systolic blood pressure was $137.44 \pm 20.93 \mathrm{mmHg}$, mean

Table 1. Distribution of subject characteristics $(n=80)$

\begin{tabular}{lc}
\hline C haracteristic & Mean \pm SD \\
\hline Age (years) & $60.6 \pm 3.30$ \\
Gender (n,\%) & $60(75.0)$ \\
Female & $20(25.0)$ \\
Male & \\
Education (n, \%) & $6(7.5)$ \\
$\quad$ No educa tion & $8(10.0)$ \\
Didnot finish primary shool & $25(31.3)$ \\
Finished primary school & $15(18.8)$ \\
Junior hi gh school & $25(31.3)$ \\
Senior high shool & $1(1.3)$ \\
Academy & \\
Employm ent (n, \%) & $38(47.5)$ \\
Employed & $42(52.5)$ \\
Unemployed &
\end{tabular}

Table 2. Mean values of serum lipid profile, blood pressure and malondialdehyde in subjects $(n=80)$

\begin{tabular}{|c|c|}
\hline Variab les & Mean \pm S.D. \\
\hline \multicolumn{2}{|l|}{ Lipid profile } \\
\hline Total chol ester ol (m g/dL) & $205.53 \pm 36.49$ \\
\hline LDL cholesterol (m g/dL) & $140.08 \pm 34.31$ \\
\hline HDL cholesterol (m $\mathrm{g} / \mathrm{dL}$ ) & $48.33 \pm 8.56$ \\
\hline Triglycerides (m g/dL) & $141.90 \pm 72.36$ \\
\hline Atherogenic index $(\%)$ & $3.34 \pm 0.92$ \\
\hline \multicolumn{2}{|l|}{ Blood pressure } \\
\hline $\begin{array}{l}\text { Systolic blood pressure } \\
(\mathrm{mmHg})\end{array}$ & $137.44 \pm 20.93$ \\
\hline $\begin{array}{l}\text { Di astolic blood presure } \\
(\mathrm{mmH} \text { ) }\end{array}$ & $84.34 \pm 11.08$ \\
\hline Malondial dehyde $(\mu M)$ & $0.35 \pm 0.09$ \\
\hline $\mathrm{B}$ ody $\mathrm{m}$ ass index $\left(\mathrm{kg} / \mathrm{m}^{2}\right)$ & $25.94 \pm 3.48$ \\
\hline
\end{tabular}

diastolic blood pressure $84.34 \pm 11.08 \mathrm{mmHg}$, mean malondialdehyde concentration (MDA) was $0.35 \pm 0.09 \mu \mathrm{M}$, and mean atherogenic index was $3.34 \pm 0.92 \%$ (Table 2).

The results of multiple linear regression analysis showed a significant association between LDL cholesterol $(\mathrm{p}=0.000)$, triglycerides $(p=0.000)$ and AI. There was no significant association between $\mathrm{AI}$ on the one hand and age $(\mathrm{p}=0.836)$, MDA, $(\mathrm{p}=0.867)$, and BMI $(\mathrm{p}=0.949)$, systolic blood pressure $(\mathrm{p}=0.477)$ and diastolic blood pressure $(\mathrm{p}=0.933)$ on the other. The variable triglyceride concentration had a great influence on $\mathrm{AI}(\beta=0.008 ; \mathrm{Beta}=0.616 ; \mathrm{p}=0.000)$ (Table 3).

\section{DISCUSSION}

Among the 80 study subjects a significant association was found between increases in AI and LDL cholesterol $(\mathrm{p}=0.000)$ and triglyceride concentration $(\mathrm{p}=0.000)$. These results are similar to the study results of Nwagha et al. ${ }^{(9)}$ who found that increases in triglyceride and total cholesterol concentrations result a higher AI. Atherogenic index is a strong indicator of cardiovascular disease. ${ }^{(3,9)}$

In this study a nonsignificant association was found between AI and MDA. Similar results were found in the study of Jasim, ${ }^{(14)}$ but different from 
Table 3. Multiple linear regression analysis of several independent variables versus atherogenic index $(n=80)$

\begin{tabular}{lccc}
\hline Variables & B & Beta & p \\
\hline Age & .005 & .019 & .836 \\
MDA & -.144 & -.015 & .867 \\
LDL cholesterol & .009 & .324 & $.000^{* *}$ \\
Triglycerides & .008 & .616 & $.000^{* *}$ \\
BMI & -.001 & -.006 & .949 \\
Systolic BP & -.004 & .083 & .477 \\
Diastolic BP & .000 & -.009 & .933 \\
\hline
\end{tabular}

Legend: $\mathrm{B}=$ regression coefficient; Beta=standardized coefficient; $\mathrm{MDA}=$ triglycerides, and malondialdehyde; $\mathrm{LDL}=\mathrm{low}$ density lipoprotein; HDL=high density lipoprotein

the results of the study of yang diperoleh Amirkhizi et al., ${ }^{(15)}$ Linna $\left.\mathrm{M}_{\text {et al }}{ }^{(16}\right)$ and Emokpae et al. ${ }^{(17)}$ who found a significant association between AI and MA. This may have been caused by the fact that the study subjects came from different populations. Our study was conducted on healthy subjects, whereas the study by Amirkhizi et al., ${ }^{(15)}$ Linna M et al. ${ }^{(16)}$ and Emokpae et al. ${ }^{(17)}$ were carried out on pre-hypertensive women, subjects with hyperlipidemia, and subjects with adult sickle cell nephropathy.

No significant association was found between AI and systolic and diastolic blood pressure This differs from the results of the study by Amirkhizi $\mathrm{F}$ et al. ${ }^{(15)}$ and Goyal et al. ${ }^{(18)}$ who found an association between changes in lipid concentrations and hypertension.

Systolic blood pressure increases progressively with advancing age, in comparison with diastolic blood pressure. Oxygen is important and also toxic to human life. Within the cell, through enzymatic and nonenzymatic processes, oxygen receives an electron and is transformed into reactive oxygen species (ROS) that damages cellular lipids, which are broken up into smaller parts, such as MDA, 8-isoprostane, 8isoprostaglandins-F2 and 8-hydroxy-2Odeoxyguanosine. Oxidative stress occurs when there is an imbalance between ROS production and the antioxidant defense system. ROS is produced naturally in normal metabolism and plays an important role in biologic processes, such as the killing of bacteria. ${ }^{(19)}$ Upon environmental stress, ROS levels increases dramatically and may damage the cellular structures, particularly when there is no defense mechanism by antioxidants, such as the enzyme SOD or the antioxidant vitamins A, C, E, and polyphenols. ${ }^{(18)}$ Vascular changes may be mediated in several ways, therefore oxidative stress may result in the proliferation of vascular smooth muscle cells accompanied by hypertrophy and accumulation of collagen, causing thickening of the tunica media and narrowing of the vascular lumen. In addition, increased oxidative stress may damage the endothelium and disturb vascular relaxation, thus increasing vascular contractile capacity. All of these influences on the blood vessels may lead to hypertension. ${ }^{(20,21)}$

In our study we did not find a significant association between $\mathrm{AI}$ and BMI. This agrees with the results of the study by Ranjit et al. ${ }^{(22)}$ who found no correlation of BMI and lipid profile with AI. In the present study there was also no significant association between AI and age. Advancing age increases the atherosclerotic process and thus AI. The lack of a significant association in this study may have been caused by the small sample size and the narrow age range. These results was in contrast with those of Nghawa UT et al. ${ }^{(10)}$ who stated that advancing age increases AI in postmenopausal women.

Epidemiological studies have shown a positive association between total cholesterol concentration and coronary heart disease. In a number of patients the total cholesterol concentration is not an accurate predictor of the risk of coronary heart disease, because total 
cholesterol is a combination of all types of cholesterol, not only atherogenic lipoproteins such as low-density lipoproteins (LDL), very-low density lipoproteins (VLDL), and intermediate lipoproteins (IDL), but also anti-atherogenic lipoproteins such as high-density lipoproteins.

Smaller LDL particles are more atherogenic than larger ones. Particles that are larger and contain much triglycerides and other smaller particles such as small VLDLs and IDLs, known as apo C-III containing lipoproteins, are extremely atherogenic.

A case-control study with prospectively collected samples found that small LDL particles and high triglyceride concentrations are the major independent risk factors for myocardial infarction. Several studies have demonstrated an inverse association between lipoprotein size and the ability to penetrate the endothelial barrier and enter the arterial intima. Chylomicrons and large VLDLs cannot enter the arterial wall, but small VLDLs and IDLs may do so. Therefore triglycerides rich in lipoproteins are termed atherogenic. ${ }^{(23)}$

The design of our study was cross sectional, so that our study cannot explain any cause-andeffect association between triglyceride concentration and AI. The clinical implication of our study results is that increased serum triglyceride concentration is a risk factor for atherogenesis. Atherosclerosis is a basic cause of heart attacks, stroke, and peripheral vascular disease. ${ }^{(1)}$ In healthy persons with high serum triglyceride concentrations but no signs of cardiovascular or cerebrovascular disease, further investigations are necessary to determine the presence or absence of vascular obstruction, particularly in the coronary arteries. Further studies of longitudinal design are necessary to show a cause-and-effect association between serum triglyceride concentration and AI.

\section{CONCLUSIONS}

The present study succeeded in demonstrating that higher serum triglyceride concentration increases AI scores in healthy subjects 50-70 years of age. Subjects with high serum triglyceride level but without symptoms of cardiovascular disease should be examined for the development of coronary artery blockage.

\section{CONFLICT OF INTEREST}

The authors declare that they have no competing interests.

\section{ACKNOWLEDGMENT}

The investigators thank the Dean and ViceDeans of Trisakti University for moral and material support in the conduct of this study. Thanks are also due to the Head of Mampang Health Center (Puskesmas Mampang) and staff and the study subjects who participated in the study.

\section{REFERENCES}

1. Yang RL, Shi YH, Hao G, et al. Increasing oxidative stress with progressive hyperlipidemia in human: relation between malondialdehyde and atherogenic index. J Clin Biochem Nutr 2008;43:154-8.

2. Prakash VB, Rao V. A study of body mass index, lipid profile, and free radical status in coronary artery disease. Int $\mathbf{J}$ Technic Res Applic 2015;3:26-8.

3. Lafta MA. A comparative study for some atherogenic indices in sera of myocardial infarction, ischemic heart disease patients and control. J Natural Sci Res 2014:121-8

4. Gomez M, Vila J, Elosua R, et al. Relationship lipid oxidation with subclinical atherosclerosis and 10-year coronary events in general population. Atherosclerosis 2014;232:134-40.

5. Vogiatzi G, Tousoulis D, Stefanadis C. The role of oxidative stress in atherosclerosis. Hellenic J Cardiol 2009;50:402-9.

6. Kaur J, Arora S, Singh B, et al. Role of oxidative stress in pathophysiology of transient ischemic attack and stroke. Int J Biol Med Res 2011:61115.

7. Mirghani Z, Zein T. Total and LDL cholesterol as risk factors of ischemic stroke in Emirate patients. Inter J Neurol 2010;1:1-5.

8. Huerta JM, Gonzalez S, Fernandez S, et al. Lipid peroxidation, antioxidant status and survival in 
institutionalised elderly: a five-year longitudinal study. Free Rad Res 2006;2:571-78.

9. Khatib FK, Samadi N, Ghojazade M, et al. Association between inflamatory factor, lipid peroxidation and total antioxidant in non diabetic patients of coronary artery disease. J.Anal Res Clin Med 2014;2:30-5.

10. Nwagha UI, Ikekpeazu EJ, Ejezie FE, et al. Atherogenic index of plasma as useful predictor of cardiovascular risk among postmenopausal woman in Enugu, Nigeria. African Health Sci 2010;3:248-52.

11. Bharadway R, Mathur K, Sharma D, et al. The relationship between oxidative stress and atherogenic index (AI) in pre eclampsia Sch J App Med Sci 2014;2:3092-6.

12. Zhou BF. Cooperative meta-analysis group of the working group on obesity in China. Predictive values of body mass index and waist circumference for risk factors of certain related diseases in Chinesse adults: study on optimal cut off point body mass index and waist circumference in Chinesse adults. Biomed Environ Sci 2002;15:83-96.

13. Morselhy HF, Reid RG, Yousef S, et al. A specific, accurate, and sensitive measure of total plasma malondialdehyde by HPLC. J Lipid Res 2013;54: 852-8

14. Jasim RH. Serum malondialdehyde and lipid profile levels of young patients "haven't a family history of hypertension": a new study for cases in the civic society. J Chem 2011;1:120-5.

15. Amirkhizi F, Siassi F, Djalali M, et al. Assessment of oxidative stress marker related to atherosclerosis in pre-hypertensive women. $\mathrm{J}$ Teh Univ Heart Circ 2007;15;137-43.
16. Linna M, Ahotupa M, Lopponen MK, et al. Circulating oxidized LDL lipids when propotined to HDL-C, emerged as a risk factor of all-cause mortality in a population-based survival study. Age Ageing 2013;42:110-3.

17. Emokpae MA, Uadia PO. Association of oxidative stress markers with atherogenic index of plasma in adult sickle cell nephropathy. Anemia 2012. Article ID 767501, 5 pages. doi: 10.1155/2012/767501.

18. Goyal R, Sarwate. A correlative study of hypertension with lipid profile. Impact J 2014;2: 143-50.

19. Sies H. Total antioxidant capacity: appraisal of concept. J Nutr 2007;137:1493-5.

20. Koenig W, Karakas M, Zievir A. Oxidized LDL and the risk of coronary heart disease: result from the Monica/Kora Augsburg study. Clin Chem 2011;57:1196-200.

21. Stocker R, Keaney JF. New insights on oxidative stress in the artery wall. J Tromb Haemost 2005; 3:1825-34.

22. Ranjit PM, Guntuku GS, Pothineni RB. New atherogenic indices: assessment of cardiovascular risk in postmenopausal dislipidemia. Asian J Medic Sci 2015;6:25-32.

23. Carmena R, Duriez P, Fruchart JP. Atherogenic lipoprotein particles in atherosclerosis. Circulation 2004;109 (23 Suppl 1):III2-7. 